\title{
KONSTRUKSI REALITAS KONFLIK INDUSTRI PENERBANGAN Framing Pemberitaan Konflik Traveloka Vs AirAsia di Detik.com
}

\author{
Euis Komalawati \\ Institut Ilmu Sosial dan Manajemen STIAMI \\ Program Studi Manajemen Komunikasi - Fakultas Ilmu Sosial dan Manajemen \\ email : komalawatieuis@gmail.com
}

\begin{tabular}{ll}
\hline ARTICLE INFO & ABSTRACT \\
\hline Keywords: & Entering into 2019, the public users of air transportation services were shocked by \\
airtransportation, & various reports on issues related to the aviation industry, from rising avtur prices, \\
Entman framing & and penetration of foreign airlines. One of the news in online media that attracted \\
public attention was the conflict between AirAsia and Traveloka as an online travel & agent (OTA). For this reason, this study was carried out to analyze the conflict \\
& reporting framing of Traveloka vs AirAsia in Detik.com online media. This study used \\
a qualitative method with Robert . Entman's framing analysis approach. The unit of \\
analysis in this study was 5 news texts about the conflict of Traveloka vs AirAsia on \\
Detik.com media. The results of the study refer to the four elements of framing \\
Entman. The first, defining the problem that the loss of AirAsia ticket distribution at \\
Traveloka is due to problems with business to business and the alleged pressure of \\
national airlines. The second, source of problems (Diagnose Causes) is Traveloka due \\
to the pressure of the national airline. The third, the moral decision (Make Moral \\
Judgment) of this problem cannot be allowed to drag on because it is a form of \\
discrimination. The fourth, emphasizing the settlement (Treatment Recommendation), \\
namely the need for dialogue between the two parties mediated by the Business \\
Competition Supervisory Commission (KPPU). The framing highlighted by Detik.com \\
in the Traveloka vs AirAsia Conflict report was a bbusiness-to-business problem, even \\
though there was an allegation that there had been an indication of an AirAsia ticket \\
distribution channel due to the pressure of the national airlanes
\end{tabular}

\section{PENDAHULUAN}

Tantangan ekonomi digital menyeruak di berbagai industri, termasuk industri transportasi baik darat, laut maupun udara. Tak dapat dipungkiri industri transportasi sangat berperan dalam kegiatan ekonomi masyarakat dan pemberdayaan masyarakat. Kegiatan ekonomi masyarakat ini akan berkembang apabila mempunyai prasarana dan sarana transportasi yang baik untuk aksesibilitas.

Tingkat mobilitas masyarakat Indonesia dari hari ke hari kian tinggi seiring perkembangan ekonomi dan perdagangan. Penggunaan jasa angkutan udara menjadi hal yang tak terelakkan mengingat posisi Indonesia yang kian strategis. Data statistik dari Badan Pusat Statistik (BPS) tahun 2018 menyebutkan jasa angkutan udara menjadi pilihan moda transportasi ketiga setelah mobil pribadi dan bus untuk aktivitas bisnis dan pariwisata. Meski demikian, pilihan akan moda transportasi udara mengalami penuruan di tahun 2018 $(4,86 \%)$ setelah sebelumnya di tahun 2016 mencapai 5,73\%. Penurunan tersebut, diduga disebabkan karena isu-isu seputar industri penerbangan akhir-akhir ini (Statistik Wisatawan Nusantara, Publikasi BPS 2018). 


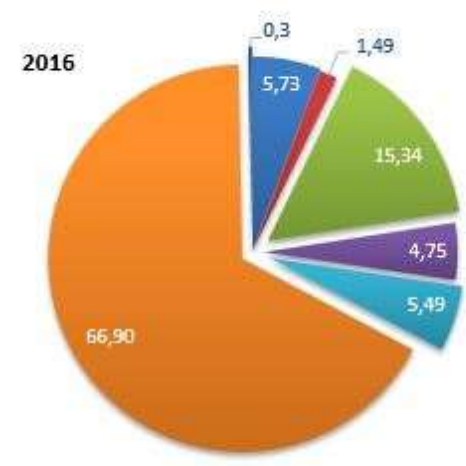

wesawat/Airplane

- Kereta Api/Train

a Bus

angkutan Air/Water

Transportation

@Travel

- Mobil Pribadi \& Sewa/Private

Vehicle \& Rent

- Lainnya/Other

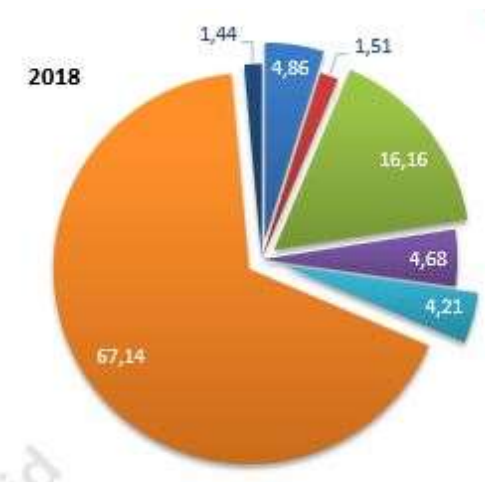

Gambar 1. Sebaran Penduduk yang Melakukan Perjalanan Menurut Moda Angkutan (persen), pada 2016 dan 2018

Sumber : Statistik Wisatawan Nusantara, Publikasi BPS 2018

Dalam industri penerbangan setidaknya terdapat lima tantangan yang harus dihadapi yakni masalah harga bahan bakar dan nilai tukar, kebutuhan awak penerbang, congestions, tarif, dan pemanfaatan teknologi digital. Tantangan tersebut ditandai dengan merangkaknya harga avtur dan penguatan dolar AS terhadap rupiah, serta beberapa faktor lainnya yang memengaruhi kinerja industri penerbangan, khususnya bagi penerbangan berjadwal dan tidak berjadwal (charter). Selain itu, perkembangan kargo udara yang sedang bertumbuh terlebih untuk wilayah timur Indonesia yang menjadi fokus pembangunan pemerintah saat ini, serta kegiatan kargo dari dan ke luar negeri.

Asosiasi Pengangkutan Udara Internasional (International Air Transport Association/IATA) memperkirakan pada 2035 Indonesia akan mengangkut 250 juta pemakai jasa penerbangan per tahun dan menduduki posisi kelima dari 10 besar dunia pasar penumpang angkutan udara. (https://swa.co.id/swa/trends/economic-issues/inaca)

Pertumbuhan industri jasa angkutan udara diramaikan pula dengan kehadiran maskapai nasional dan pertumbuhan perusahaan Online Travel Agent (OTA) seperti Traveloka, Tiket.com, PegiPegi, Mister Aladin dan lain-lain. Maraknya kompetisi dalam industri penerbangan tak heran menimbulkan berbagai persoalan. Memasuki awal tahun 2019, publik pengguna jasa transportasi udara dikejutkan dengan berbagai pemberitaan permasalahan seputar industri penerbangan, mulai dari kenaikan harga avtur, tingginya tiket penerbangan domestik, penghapusan layanan bagasi gratis hingga kompetisi dan penetrasi maskapai asing. Salah satu pemberitaan di media online yang menarik perhatian publik adalah konflik AirAsia dan Traveloka sebagai online travel agent (OTA).

Beberapa kajian tentang Framing pemberitaan Media Online terkait transportasi pernah dilakukan, antara lain pertama Humaira, Tsania (2017) dalam penelitian berjudul Konstruksi Media Online Pada Pemberitaan Pemblokiran Transportasi Berbasis Aplikasi (Uber Dan Grab Car). Tsania menunjukkan framing yang dilakukan Kompas.com lebih mendukung adanya pemblokiran transportasi berbasis aplikasi. Kompas.com memposisikan pihak transportasi konvensional sebagai pihak yang terpojok. Sedangkan framing yang dilakukan Detik.com lebih menentang pemblokiran transportasi aplikasi bahwa pemblokiran bukan solusi yang tepat karena disisi lain menguntungkan masyarakat dan menganggap persoalan ini ditujukan kepada pihak pemerintah yang diharapkan tegas dalam mengambil keputusan mengakomodasi atau menertibkan melalui argument narasumber dalam beritanya. Penelitian kedua dilakukan Mutia Rahmi dkk dalam penelitian Konvensional Vs Online ? Analisis Framing Berita Demo Taksi Dalam Media Online Tempo.Com, dimana ia menyatakan pihak media online tempo.com mengajak pembaca untuk pro terhadap transportasi berbasis aplikasi online. Ketiga, Persulessy dan Stella Fellicia (2016) dalam penelitiannya berjudul Analisis Pemberitaan Go-Jek dan GrabBike di Masa Awal Peluncuran Jasa Transportasi Online (Studi pada pemberitaan di Kompas.com), memaparkan hasil penelitian menunjukan bahwa Kompas.com sama-sama membingkai Go-Jek dan GrabBike secara positif, namun perbedaannya adalah berita Go-Jek banyak dibingkai dari sisi penilaian pemerintah Jakarta terhadap layanan Go-Jek yang dinilai sebagai sebuah inovasi, sedangkan berita GrabBike dibingkai dari sisi keberhasilan aplikasinya.

Ketiga penelitian diatas menguatkan pentingnya penelitian tentang konstruksi pemberitaan atas suatu realitas. Konstruksi pemberitaan tersebut tidak lepas dari faktor-faktor nilai berita, selera pasar atau minat pembaca, dan kepentingan pasar media. 
Isu konflik AirAsia dan Traveloka sebagai online travel agent (OTA) mengemuka dan menjadi headline di beberapa media online pada awal bulan Februari 2019. Konflik tersebut dipicu akibat hilangnya penjualan tiket maskapai AirAsia di beberapa OTA termasuk di Traveloka. Banyak dugaan yang muncul dalam kasus tersebut, di antaranya karena persaingan industri hingga dugaan kartel dalam industri penerbangan tanah air. Sedikitnya terdapat 10 (sepuluh) pemberitaan tentang Konflik AirAsia vs Traveloka yang dimuat dalam detik.com sebagaimana ditampilkan dalam tabel berikut :

Tabel 1. Pemberitaan Traveloka Vs AirAsia di Detik.com

\begin{tabular}{|c|c|c|}
\hline No & Tanggal, waktu & Judul Berita \\
\hline 1 & Senin, 25 Mar 2019 21:00 WIB & $\begin{array}{l}\text { AirAsia: Kita Berharap Tiket Bisa Dijual di } \\
\text { Traveloka Cs Lagi }\end{array}$ \\
\hline 2 & Senin, 25 Mar 2019 19:14 WIB & $\begin{array}{l}\text { AirAsia Dipanggil KPPU soal Tiket } \\
\text { 'Hilang' di Traveloka Cs, Bahas Ini }\end{array}$ \\
\hline 3 & Senin, 25 Mar 2019 18:05 WIB & $\begin{array}{l}\text { KPPU: Tiket AirAsia Tak Hanya Hilang di } \\
\text { Traveloka, Tapi di } 15 \text { Tempat }\end{array}$ \\
\hline 4 & Jumat, 22 Mar 2019 09:59 WIB & $\begin{array}{l}\text { Soal AirAsia-Traveloka 'Cerai', INACA } \\
\text { Bantah Ada Tekanan Maskapai Lain }\end{array}$ \\
\hline 5 & Jumat, 15 Mar 2019 23:30 WIB & $\begin{array}{l}\text { AirAsia-Traveloka 'Cerai' karena Tekanan } \\
\text { Maskapai? Menhub: Nggak Mungkin! }\end{array}$ \\
\hline 6 & Jumat, 15 Mar 2019 15:00 WIB & $\begin{array}{l}\text { AirAsia Traveloka 'Cerai' Gara-gara } \\
\text { Tekanan Maskapai Lain? }\end{array}$ \\
\hline 7 & Rabu, 06 Mar 2019 06:54 WIB & Kisah 'Cerai' AirAsia dan Traveloka \\
\hline 8 & Selasa, 05 Mar 2019 15:56 WIB & Akankah AirAsia dan Traveloka 'Rujuk'? \\
\hline 9 & Selasa, 05 Mar 2019 14:28 WIB & Sebab Musabab AirAsia-Traveloka 'Cerai' \\
\hline 10 & Selasa, 05 Mar 2019 11:08 WIB & $\begin{array}{l}\text { Begini Skema Bisnis AirAsia dan } \\
\text { Traveloka Sebelum 'Cerai' }\end{array}$ \\
\hline
\end{tabular}

Untuk mengungkapkan konstruksi realitas atas konflik AirAsia vs Traveloka dalam detik.com, penulis menggunakan pendekatan framing Robert N. Entman yang mendefiniskan framing, sebagai: "Proses seleksi dari berbagai aspek realitas sehingga bagian tertentu dari peristiwa itu lebih menonjol dari pada aspek lain. Ia juga menempatkan informasi-informasi dalam konteks yang khas sehingga sisi tertentu mendapatkan alokasi lebih besar dari pada sisi yang lain".

Entman melihat frame dalam dua dimensi besar, yakni seleksi isu dan penonjolan isu. Penonjolan adalah proses membuat informasi menjadi lebih bermakna, lebih menarik, lebih berarti atau lebih diingat oleh khalayak. Realitas yang disajikan secara mencolok atau menonjol mempunyai kemungkinan lebih besar untuk diperhatikan dan mempengaruhi khalayak dalam memahami suatu realitas. Dalam prakteknya, framing dijalankan media dengan menseleksi isu tertenyu dan mengabaikan isu yang lain; dan menonjolkan aspek dari isu tersebut dengan menggunakan berbagai strategi penempatan yang mencolok di bagian depan, pengulangan, pemakaian grafis dan foto, kata yang mudah diingat dan sebagainya. Semua aspek tersebut membuat dimensi tertentu konstruksi berita menjadi lebih diingat oleh khalayak. (Eriyanto, 2011)

Dalam konsepsi Entman, framing pada dasarnya merujuk kepada pemberian definisi, penjelasan, evaluasi dan rekomendasi dari stau berariya untuk menekankan kerangka berpikir tertentu terhadap peristiwa yang diberitakan.

Menurut Entman, framing dalam berita dilakukan dengan empat cara, yakni: 1. Define problems. Merupakan elemen yang pertama kali dapat kita lihat mengenai framing, yang merupakan master frame paling utama. Ia menekankan bagaimana peristiwa dipahami oleh wartawan, ketika ada masalah atau peristiwa. 2. Diagnose causes. Merupakan elemen framing untuk membingkai siapa yang dianggap sebagai aktor utama suatu peristiwa. Penyebab disini bisa berarti apa (what), tetapi bisa juga berarti siapa (who). 3 . Make moral judgement. Merupakan elemen framing yang digunakan untuk membenarkan argumentasi pada pendefinisian masalah yang sudah dibuat. Gagasan yang dikutip berhubungan dengan sesuatu yang familiar dan dikenal oleh khalayak. 4. Treatment recommendation. Elemen ini digunakan untuk menilai apa yang dikehendaki oleh wartawan. Jalan apa yang dipilih untuk menyelesaikan masalah. Penyelesaian tersebut 
sangat tergantung pada bagaimana peristiwa itu dilihat dan siapa yang dipandang sebagai penyebab masalah (Qodari, 2000:20).

Analisis konstruksi realitas konflik AirAsia vs Traveloka dalam media online ini menggunakan pendekatan Konstruksi Realitas yang dikemukakan Berger dan Luckmann. Menurut teori ini realitas sosial menggunakan beberapa konsep eksternalisasi, objektivasi (objectivation), dan internalisasi (internalisation). Eksternalisasi adalah usaha pencurahan diri manusia ke dalam dunia, baik dalam kegiatan mental maupun fisik (Berger \& Luckmann, 1967). Eksternalisasi merupakan interaksi sosial antara manusia dengan struktur sosial yang sudah ada. Sedangkan objektivasi merupakan proses manifestasi diri (pengungkapan kenyataan subjektif) kedalam bentuk-bentuk kegiatan yang tersedia yang bisa diketahui oleh orang lain sebagai unsurunsur dari dunia bersama. Konsep internalisasi merujuk pada pemahaman atau penafsiran yang langsung dari suatu peristiwa objektif sebagai pengungkapan suatu makna. Atau memahami proses-proses subjektif orang lain menjadi bermakna bagi kita.

Berdasarkan pemaparan diatas, penulis tertarik untuk mengungkapkan bagaimana detik.com sebagai salah satu media online membingkai realitas konflik AirAsia vs Traveloka dalam konstruksi pemberitaannya.

\section{METODE PENELITIAN}

Penelitian ini menggunakan metode kualitatif dengan pendekatan framing. Framing digunakan untuk menganalisis pembingkaian yang dikonstruksikan oleh media dalam merepresentasikan realitas. Realitas konflik antara AirAsia dan Online Travel Agent (OTA) yakni Traveloka dan Tiket.com dikonstruksikan oleh media online detik.com dengan sudut pandang konstruksionisme.

Teknik pengumpulan data dilakukan dengan dokumentasi teks berita tentang konflik AirAsia vs Traveloka di detik.com sejak awal Februari hingga Maret 2019. Dari sejumlah teks berita, penulis menentukan 5 (lima) teks teraktual dari aspek waktu, yakni pada tanggal 15 - 25 Maret 2019.

Teknik analisis data dengan menggunakan pendekatan Framing Robert Entman yang membongkar teks melalui 4 (empat) perangkat framing yakni : (1) Pendefinisian Masalah (Define Problems) yakni Bagaimana suatu peristiwa dilihat ? Sebagai apa? Atau sebagai masalah apa; (2) Sumber Masalah (Diagnose Causes) yakni Peristiwa dilihat disebabkan oleh apa? Siapa aktor yang dianggap sebagai penyebab masalah?; (3) Keputusan Moral (Make Moral Judgment) yakni Nilai moral apa yang disajikan untuk menjelaskan masalah? Nilai moral apa yang dipakai untuk mendukung atau tidak mendukung suatu tindakan?; dan (4) Menekankan Penyelesaian (Treatment Recommendation) yaitu Penyelesaian apa yang ditawarkan untuk mengatasi masalah?.

\section{HASIL PENELITIAN DAN PEMBAHASAN}

Hasil penelitian ini dideskripsikan melalui analisis framing pada 5 (lima) teks berita konflik AirAsia vs Traveloka di media online detik.com periode 15 - 25 Maret 2019, sebagai berikut :

Tabel 2. Analisis Framing Berita 1

\begin{tabular}{ll}
\hline Perangkat Framing & $\begin{array}{l}\text { Judul : AirAsia: Kita Berharap Tiket Bisa Dijual di } \\
\text { Traveloka Cs Lagi }\end{array}$ \\
\hline Problem Identification & $\begin{array}{l}\text { Tiket AirAsia hilang di beberapa OTA seperti } \\
\text { Traveloka, Tiket.com dan lainnya. }\end{array}$ \\
Causal Interpretation & $\begin{array}{l}\text { AirAsia sendiri telah men-suspend alias menarik diri } \\
\text { dari OTA setelah tahu tiket yang dijual hilang. Namun, }\end{array}$ \\
& $\begin{array}{l}\text { AirAsia menilai keputusan penarikan penjualan itu } \\
\text { merupakan keputusan bisnis. }\end{array}$ \\
Moral Evaluation: & $\begin{array}{l}\text { Pihak OTA tidak memiliki itikad baik untuk } \\
\text { menyelesaikan permasalahan dan tidak } \\
\text { mengklarifikasikannya melalui komunikasi. }\end{array}$ \\
Treatment Recommendation & $\begin{array}{l}\text { ada diskusi dan pembicaraan antara pihak AirAsia dan } \\
\text { pihak OTA. }\end{array}$ \\
\hline
\end{tabular}

Sumber : berita dimuat di detik.com tanggal 25 Maret 2019 
Tabel 3. Analisis Framing Berita 2

\begin{tabular}{ll}
\hline Perangkat Framing & $\begin{array}{l}\text { Judul : AirAsia Dipanggil KPPU soal Tiket 'Hilang' } \\
\text { di Traveloka Cs, Bahas Ini }\end{array}$ \\
\hline Problem Identification & $\begin{array}{l}\text { KPPU memanggil AirAsia untuk dimintai keterangan } \\
\text { mengenai insiden hilangnya tiket AirAsia di beberapa } \\
\text { OTA }\end{array}$ \\
Causal Interpretation & $\begin{array}{l}\text { KPPU menduga ada yang menghalangi proses distribusi } \\
\text { tiket AirAsia. }\end{array}$ \\
Moral Evaluation: & $\begin{array}{l}\text { AirAsia bersikap kooperatif, memberikan laporan saat } \\
\text { dipanggil KPPU dan beritikad baik menyelesaikan } \\
\text { permasalahan tanpa melalui jalur hukum } \\
\text { KPPU memangil OTA, stakeholder dan lainnya untuk } \\
\text { menyelesaikan permasalahan tersebut }\end{array}$ \\
\hline
\end{tabular}

Sumber : berita dimuat di detik.com tanggal 25 Maret 2019

Tabel 4. Analisis Framing Berita 3

\begin{tabular}{ll}
\hline Perangkat Framing & $\begin{array}{l}\text { Judul : KPPU: Tiket AirAsia Tak Hanya Hilang di } \\
\text { Traveloka, Tapi di 15 Tempat }\end{array}$ \\
\hline Problem Identification & $\begin{array}{l}\text { Komisi Pengawas Persaingan Usaha (KPPU) akan } \\
\text { melakukan inisiatif penelitian terhadap kasus hilangnya } \\
\text { tiket AirAsia di beberapa Online Travel Agent (OTA) }\end{array}$ \\
Causal Interpretation & $\begin{array}{l}\text { KPPU mencurigai ada yang melakukan usaha } \\
\text { penghadangan pada jalur distribusi tiket AirAsia }\end{array}$ \\
Moral Evaluation: & $\begin{array}{l}\text { KPPU sebagai Komisi Pengawas Persaingan Usaha } \\
\text { berinisiatif melakukan penelitian sebagai bentuk } \\
\text { tanggung jawab pada para pelaku usaha. }\end{array}$ \\
Treatment Recommendation & $\begin{array}{l}\text { AirAsia datang untuk menyampaikan permasalahannya } \\
\text { ke KPPU. Tidak hanya di publik saja sehingga bisa jadi } \\
\text { alat bukti penegakan hukum }\end{array}$ \\
\hline
\end{tabular}

Sumber : berita dimuat di detik.com tanggal 25 Maret 2019

Tabel 5. Analisis Framing Berita 4

\begin{tabular}{ll}
\hline Perangkat Framing & $\begin{array}{l}\text { Judul : Soal AirAsia-Traveloka 'Cerai', INACA } \\
\text { Bantah Ada Tekanan Maskapai Lain }\end{array}$
\end{tabular}

Problem Identification $\quad$ Tiket pesawat maskapai Air Asia telah menghilang di beberapa situs online travel agent (OTA). Air Asia pun sudah menghentikan beberapa kerja sama dengan OTA besar di Indonesia.

Causal Interpretation Indonesia National Air Carrier Association (INACA) menyebutkan wajar persaingan terjadi dengan ketat. Hal tersebut menurutnya menepis anggapan bahwa dunia penerbangan Indonesia berada dalam tangan kartel.

$\begin{array}{ll}\text { Moral Evaluation: } & \begin{array}{l}\text { Masing-masing pihak kembali pada kesepakatan bisnis. } \\ \text { Maskapai memiliki kesepakatan dengan para OTA. } \\ \text { Selanjutnya, tinggal OTA yang memilih mana maskapai } \\ \text { yang menguntungkan. }\end{array} \\ \text { Treatment Recommendation } & \begin{array}{l}\text { INACA meminta media asing yang memberitakan } \\ \text { tentang kartel dan intervensi penjualan tiket pada OTA } \\ \text { untuk membuktikan dugaan tersebut. }\end{array}\end{array}$

Sumber : berita dimuat di detik.com tanggal 22 Maret 2019 
Tabel 6. Analisis Framing Berita 5

\begin{tabular}{ll}
\hline Perangkat Framing & $\begin{array}{l}\text { Judul : AirAsia-Traveloka 'Cerai' karena Tekanan } \\
\text { Maskapai? Menhub: Nggak Mungkin! }\end{array}$ \\
\hline Problem Identification & 'perceraian' Traveloka dengan AirAsia \\
Causal Interpretation & $\begin{array}{l}\text { Menurut Menteri Perhubungan ini disebabkan } \\
\text { permasalahan business to business, sehingga tidak } \\
\text { mungkin Traveloka itu mau ditekan oleh pihak lain, } \\
\text { karena menyangkut kredibilitasnya. }\end{array}$
\end{tabular}

$\begin{array}{ll}\text { Moral Evaluation: } & \begin{array}{l}\text { Kredibilitas Traveloka sebagai OTA dipertaruhkan } \\ \text { dalam kasus ini jika dugaan mengarah pada tekanan } \\ \text { maskapai besar nasional. }\end{array} \\ \text { Treatment Recommendation } & \begin{array}{l}\text { Traveloka harus menyelesaikan dengan AirAsia melalui } \\ \text { klarifikasi dan komunikasi karena menyangkut } \\ \text { kredibilitasnya }\end{array}\end{array}$

Sumber : berita dimuat di detik.com tanggal 15 Maret 2019

\section{ANALISIS DAN INTERPRETASI}

Dalam industri penerbangan, kompetisi antar maskapai penerbangan adalah sesuatu yang tak terelakkan. Realitas kompetisi industri diangkat oleh media bagian dari interaksi satu sama lain. Tarik menarik kepentingan di antara stakeholder industri penerbangan merupakan bagian dari struktur sosial yang terbangun. Interaksi sosial antar stakeholder berlaku dalam struktur sosial yang ada. Interaksi sosial dalam struktur masyarakat yang melahirkan konflik antara maskapai penerbangan AirAsia dan OTA Traveloka merupakan bentuk dari eksternalisasi. Dalam eksternalisasi setiap individu memperhitungkan tipifikasitipifikasi. Konflik AirAsia dan OTA Traveloka dalam interaksi sosial memiliki tipifikasi yang dipahami dalam masyarakat dalam berbagai tipe. Beberapa kalangan menilai konflik ini dilatarbelakangi persaingan usaha, sementara sebagian lain menilai sebagai konflik b-to-b yang lazim dalam sebuah bisnis. Namun yang paling mengejutkan adalah dugaan adanya kartel dan intervensi pendistribusian tiket oleh maskapai nasional.

Berkembangnya isu seputar konflik AirAsia vs Traveloka melahirkan tipifikasi yang berbeda dari berbagai kalangan khususnya stakeholder penerbangan seperti pemerintah dalam hal ini Kementerian Perhubungan, Komisi Pengawas Persaingan Usaha (KPPU), Indonesia National Air Carrier Association (INACA), Maskapai Penerbangan, Online Travel Agent dan masyarakat sebagai konsumen. Perubahan tipifikasi ini secara lambat laun mengubah tatanan sosial dan stigma tentang industri penerbangan, akibatnya terjadi perubahan sosial.

Objektivasi konflik AirAsia vs Traveloka merupakan proses manifestasi (pengungkapan kenyataan subjektif) kedalam bentuk-bentuk kegiatan yang tersedia yang bisa diketahui oleh orang lain sebagai unsurunsur dari dunia bersama. Dalam framing detik.com, manifestasi konflik diangkat sebagai sebuah permasalahan b-to-b (bussines to bussines), meski kemudian muncul dugaan adanya penghadangan jalur distribusi tiket AirAsia akibat tekanan maskapai nasional. Framing detik.com mengangkat narasumber dari Traveloka, KPPU, INACA dan bahkan Menteri Perhubungan, namun tidak menampilkan narasumber dari pihak OTA Traveloka.

Makna konflik AirAsia vs Traveloka semula memiliki pemahaman sebagai permasalahan bussines to bussines pada awalnya, diframing detik.com bahwa Pihak OTA tidak memiliki itikad baik untuk menyelesaikan permasalahan dan tidak mengklarifikasikannya melalui komunikasi. Framing lain yang diangkat detik.com bahwa KPPU menduga ada yang menghalangi proses distribusi tiket AirAsia. Namun detik.com berupaya membingkai secara balance dengan mengangkat Indonesia National Air Carrier Association (INACA) yang menyebutkan wajar persaingan terjadi dengan ketat, untuk menepis anggapan bahwa dunia penerbangan Indonesia berada dalam tangan kartel. Proses internalisasi, yaitu pemahaman atau penafsiran seketika tentang konflik AirAsia vs Traveloka dalam masyarakat kita awalnya mengantarkan pada ekspresi kelompok yang cenderung negatif. Namun proses subjektivisme yang diframing dalam detik.com tentang konflik tersebut menunjukan keragaman subjektivitas, yang dalam interaksi sosial mempertemukan dua atau lebih subjektivitas. Internalisasi yang merupakan basis paling awal dalam pemahaman tentang

Euis Komalawati et al. (Konstruksi Realitas Konflik Industri Penerbangan Framing Pemberitaan Konflik...) 
realitas sosial konflik AirAsia vs Traveloka yang diframing oleh detik.com sebagai permasalahan bussines to bussines hingga dugaan adanya kartel dalam distribusi tiket akibat tekanan maskapai-maskapai nasional, memuncak hingga pada derajat internalisasi tertentu mendukung proses sosialisasi.

\section{SIMPULAN}

Berdasarkan hasil penelitian maka dapat disimpulkan merujuk pada empat elemen framing Entman yakni, pertama pendefinisian masalah (Define Problems) bahwa hilangnya pendistribusian tiket AirAsia di Traveloka karena adanya permasalahan bussines to bussines dan dugaan tekanan maskapai nasional. Kedua, sumber masalah (Diagnose Causes) adalah pihak Traveloka akibat tekanan maskapai nasional. Ketiga, keputusan moral (Make Moral Judgment) permasalahan ini tidak bisa dibiarkan berlarut-larut karena merupakan bentuk diskriminasi. Keempat, menekankan penyelesaian (Treatment Recommendation) yakni perlu dilakukan dialog komunikasi dan klarifikasi kedua belah pihak ditengahi oleh Komisi Pengawas Persaingan Usaha (KPPU). Framing yang ditonjolkan oleh Detik.com dalam pemberitaan Konflik Traveloka vs AirAsia adalah permasalahan b-to-b (bussines to bussines), meski kemudian muncul dugaan adanya penghadangan jalur distribusi tiket AirAsia akibat tekanan maskapai nasional.

\section{DAFTAR PUSTAKA}

Berger, Peter \& Luckmann, Thomas (1967). The Social Construction of Reality, a Treatise in the Sociological of Knowledge.London : Penguin Books.

Eriyanto. (2011). “Analisis Framing”: Konstruksi Ideologi, dan Politik Media. Yogyakarta: Lkis.

Humaira, Tsania (2017) Konstruksi Media Online Pada Pemberitaan Pemblokiran Transportasi Berbasis Aplikasi (Uber Dan Grab Car) (Analisis Framing Pada Kompas.Com Dan Detik.Com Periode 14 Maret 2016). Other Thesis, University Of Muhammadiyah Malang.

Rahmi, Mutia.,Yusrianam Amida. \& Mukaromah. (2016). Konvensional Vs Online ? Analisi Framing Berita Demo Taksi Dalam Media Online Tempo.Com. Thesis, Universitas Dian Nuswantoro (Udinus) Semarang

Nugroho, B., Eriyanto, Frans Sudiarsis. (1999). Politik Media Mengemas Berita. Jakarta : Institut Studi Arus Informasi.

Persulessy, Stella Fellicia (2016) Analisis Pemberitaan Go-Jek Dan Grabbike Di Masa Awal Peluncuran Jasa Transportasi Online (Studi Pada Pemberitaan Di Kompas.Com). Undergraduate (S1) Thesis, Universitas Bakrie.

Sobur, A. (2012). Analisis Teks Media: Suatu Pengantar untuk Analisis Wacana, Analisis Simiotik, dan Analisis Framing. Bandung: Remaja Rosdakarya.

Qodari, Muhammad. (2000). Papua Merdeka dan Pemaksaan Skenario Media. Jurnal Pantau 08. Hlm 19 25. 